\title{
Aneta Majkowska, Debata sejmowa jako gatunek wypowiedzi, Wydawnictwo WCM, Opole 2012,
}

\section{ss. 294}

Książka Anety Majkowskiej sytuuje się w obszarze genologii lingwistycznej. Sama autorka tak określa jej przedmiot i cel: „Przedmiotem zainteresowania czynię współczesną polską debatę sejmową. Za cel stawiam opisanie jej cech gatunkowych. Debata sejmowa, szczególnie po transformacji ustrojowej, stała się złożonym zdarzeniem komunikacyjnym. Poddanie obserwacji tego obiektu pozwala badać użycie języka oraz komunikację językową w jednej z istotnych przestrzeni życia publicznego i w dynamicznie zmieniającej się rzeczywistości społecznej. Gatunek debaty sejmowej badam w aspekcie lingwistyczno-genologicznym. Obserwuję go jednocześnie z perspektywy kulturowo-pragmatycznej. Gatunek wypowiedzi traktuję tym samym jako konwencję kulturowo-językową. [...] Badam autentyczne zachowania komunikacyjne $\mathrm{i}$ ich tekstowe efekty na poziomie werbalnym, parawerbalnym i niewerbalnym" (s. 9).

Podstawę źródłowo-materiałową rozprawy stanowią ,projekty ustaw, informacje rządu, sprawozdania z prac komisji, wnioski o wotum nieufności, oświadczenia, pytania poselskie, sprostowania, odniesienia do oświadczeń i pytań poselskich" (s. 9). Autorka objęła badaniami 50 debat sejmowych, nagranych w latach 2007-2011 na płyty DVD przez Kancelarię Sejmu. Taką podstawę źródłowo-materiałową należy uznać za satysfakcjonująca.

W kwestii przyjętej w pracy metodologii deklaracja autorki brzmi dość ogólnikowo: „W pracy korzystam z osiagnięć genologii lingwistycznej wypracowanych w ośrodkach: opolskim, lubelskim i katowickim. Do uporządkowania wzorca gatunkowego debaty sejmowej posłużyły mi głównie ustalenia szkoły opolskiej. Badacze opolscy przy opisie gatunku uwzględniają aspekty: pragmatyczny, strukturalny, poznawczy oraz stylistyczny i bazują na analizie 
dynamicznej umożliwiającej ukazanie kierunków przemian dokonujących się we wzorcu gatunkowym" (s. 9). Dla specjalistów genologów, dobrze zorientowanych w dorobku i specyfice wspomnianych przez autorkę szkół genologii lingwistycznej, mimo swej ogólnikowości jest to deklaracja wystarczająca.

Wychodząc z wyżej scharakteryzowanych założeń teoretyczno-metodologicznych (wyczerpująco przedstawionych w rozprawie co do teorii, ogólnikowo co do metodologii) i poddając wnikliwej analizie reprezentatywny materiał językowy, osiągnęła autorka zamierzony cel badawczy. Powstała praca solidna, sumienna, obszerna i w zamierzonym zakresie wyczerpująca. O jej wartości stanowią - moim zdaniem - przede wszystkim następujące aspekty i elementy:

1. Wybór tematu rozprawy. Rola Sejmu w naszym kraju po transformacji ustrojowej w roku 1989 powoduje to, że debata sejmowa wysuwa się na czoło gatunków wypowiedzi w dyskursie politycznym, stanowiącym w dużej mierze o jakości naszego życia zbiorowego. Stąd multidyscyplinarne zainteresowanie naukowe debatą sejmową - m.in. zainteresowanie ze strony językoznawstwa, zwłaszcza genologii lingwistycznej, wyrażane, jak słusznie przypomina autorka, już w 1994 roku w 11. tomie serii Język a Kultura, zatytułowanym Język polityki a współczesna kultura polityczna. Można więc powiedzieć, że rozprawa Anety Majkowskiej jest urzeczywistnieniem postulatu sprzed prawie dwudziestu lat.

2. Zgodne z tendencjami współczesnego językoznawstwa założenia teoretyczno-metodologiczne i racjonalne instrumentarium badawcze.

3. Samoistna wartość informacyjna wstępnych paragrafów poświęconych pojęciu gatunku (autorka zdobyła się na krytyczne omówienie współczesnych koncepcji genologicznych, relacji gatunku do stylu, dyskursu i tekstu, systematyzacji gatunków, stanu badań nad gatunkami itd.).

4. Imponujące zaplecze erudycyjne rozprawy. Bibliografia (s. 235-264) obejmuje aż 578 pozycji, z czego większość, bo 311 pozycji, to książki, nieraz wielotomowe (trzeba też dodać, że autorka wyzyskuje nie tylko polską i obcą, lecz dostępną w języku polskim (w polskich przekładach) literaturę przedmiotu: w spisie bibliografii widnieje 20 prac w języku angielskim, 9 we francuskim i 2 w niemieckim). Należy przy tym podkreślić, że ten imponujący zestaw bibliograficzny bynajmniej nie ma na celu erudycyjnego popisu: gruntowna i krytyczna znajomość rozległej i multidyscyplinarnej literatury przedmiotu ma w rozprawie charakter wysoce sfunkcjonalizowany.

5. Gruntowność, wielostronność, wnikliwość i szczegółowość przeprowadzonych w rozprawie analiz i interpretacji. Badaczka ustaliła cechy gatunkowe debaty sejmowej (uwzględniając jej tło pragmatyczne, funkcje, tematykę, etykietę sejmową itd.), tworząc w ten sposób jej wzorzec gatunkowy, a następnie 
prześledziła realizację tego wzorca, analizując trzy podstawowe elementy debaty: wypowiedzi inicjalne i finalne oraz rozdzielająca je dyskusję. Pod uwage wzięła takie parametry, jak sytuacja komunikacyjna, uczestnicy, struktura formalna (w tym segmentacja wertykalna i horyzontalna, wyznaczniki segmentacji i delimitacji), akty grzecznościowe (tu też grzeczność pozorna, naruszanie zasad grzecznościowych, agresja językowa), organizacja tematyczna itd. Nie ograniczając się do komunikacji werbalnej, uwzględniła też parawerbalną i niewerbalną - kinezyjną, czyli gesty i mimikę: zobrazowaniu gestykulacji mówców sejmowych poświęcony jest Aneks (s. 271-294). Niepodobna się zgodzić z niektórymi ustaleniami etymologicznymi autorki, np. mimo kilku szczegółów z dziejów debaty w języku polskim wymagających jeszcze wyjaśnienia nie ulega najmniejszej watpliwości, że jest to w polszczyźnie galicyzm (zapożyczenie z francuskiego débat): późnołacińskie debattuere nie ma tu nic do rzeczy (poza tym, że jest formą wyjściową francuskiego débattre, podstawy słowotwórczej rzeczownika débat), a angielskie debate mogło ewentualnie wywrzeć pewien wpływ znaczeniowy na polską debatę.

6) I wreszcie - jako skutek wyliczonych wyżej walorów - liczne interesujące wyniki naukowe. Autorka zebrała je w kilkustronicowym Zakończeniu (s. 223-229). Jest to tekst tak „gęsty”, że niepodobna w nim pominąć choćby jednego zdania, toteż nie nadaje się do streszczenia czy omówienia - można jedynie do niego odesłać zainteresowanego czytelnika. $Z$ jednym wszakże twierdzeniem Majkowskiej trudno by mi było się zgodzić. Autorka pisze: „Uczestnicy debaty reprezentują wspólną bazę kulturowa, czyli podlegają ogólnym normom i wartościom wspólnie podzielanym. Tworzą społeczność dyskursywną, czyli wspólnotę ideowo-kulturową zbudowaną na określonej wizji świata. Tym, co dzieli uczestników debaty, są modele mentalne, czyli osobiste doświadczenia mówiących oraz ich pamięć epizodyczna" (s. 224). Może (choć wątpię) tak jeszcze było w momencie, gdy autorka pisała te słowa, ale na pewno nie jest tak dziś (a data wydania książki to 2012!). „Prawdziwi Polacy” i „lemingi” to dwa całkowicie odrębne społeczeństwa, które dzieli wszystko, a których już nie łączy nic: ani wspólna wizja świata, ani wspólnie podzielany system wartości. Ale to już oczywiście kwestia, która nie może rzutować na ocenę monografii.

Z satysfakcją należy odnotować, że polska genologia lingwistyczna wzbogaciła się o kolejną wartościową i ważną (ze względów zarówno stricte naukowych, jak i społecznych) pozycję. 